\title{
MAREK KAŹMIERCZAK
}

Poznań-Gniezno

\section{Bunt mas w zjednoczonej Europie}

\section{Wstęp}

Masy istnieją od czasu, w którym wspólnoty międzyludzkie zaczęły podlegać wewnętrznym oraz zewnętrznym podziałom ekonomicznym, religijnym, kulturowym, życiowym, politycznym, a także w ich perspektywie - światopoglądowym. Ich funkcjonowanie oraz zmiana taktyk działania ulegały w kulturze zachodniej mutacjom od XIX wieku, gdy relacje między rządzącymi a rządzonymi zaczęły określać rozwijające się technologie, środki przekazu oraz sposoby systemowego nadzoru społecznego ciała $^{1}$. Do mas zaliczało się tych wszystkich, którzy nie umieli zaznaczyć na mapie historii swojej obecności w sposób trwały, tak jak czyniły to instytucje skupiające „znakomitych przedstawicieli różnych mniejszości” (np. wyłaniających się jako skutek różnic w dostępie do dóbr materialnych lub sprawowanych urzędów) czy możni ludzie, którzy do dziś spoglądają na współczesnego człowieka z nieznośną lekkością własnej, czasowej wyższości odmalowanej na płótnach i wyrzeźbionej w marmurach najwybitniejszych artystów.

Zderzenie człowieka z historią kończy się opowieściami, które - gdy przeradzały się w histerie - prowadziły do zniszczeń. Masy, ich anonimowe śmierci ${ }^{2}$, stygmatyzowały historię wtedy, gdy na jej co dzień odradzającym się dziewiczym łonie zapomnienia i nadziei zostawiały pieczęć zniszczenia albo rewolucji. Masy w historii były nieme, jeśli myśli się o trwałych śladach w postaci tworzonych przez nie narracji. Pierwszy raz masy przebiły się przez kokon historii we Francji ${ }^{3}$, dając asumpt do zrywu społecznego umysłom wymęczonym podówczas tradycyjnym, politycznie i religijnie gwarantowanym pozorem, a jeszcze niezdolnym do uniesień na miarę potęgi rozumu

1 J. Douglas, Disappearing Citizenship: surveillance and the state of exception, „Surveillance \& Society" 2009, nr 6(1), s. 34, http://www.surveillance-and-society.org (17.08.2009).

2 Paul Ricoeur pisał, że anonimowa śmierć tych wszystkich ludzi, którzy jedynie milcząco przechodzą przez scenę historii, zmusza do refleksji dotyczącej sensu tej anonimowości. Zwykłemu umieraniu, temu ,umiera się” francuski filozof starał się „przywrócić ontologiczną gęstość pod dwoistym znakiem okrucieństwa gwałtownej śmierci i równości śmierci, która zrównuje wszystkie losy". Dla historii szczególnie ważna jest bowiem taka właśnie śmierć, która paradoksalnie jest formą nieobecności w niej. P. Ricoeur, Pamięć, historia, zapomnienie, tłum. J. Margański, Kraków 2006, s. 486.

3 Długa historia człowieka masowego zdaniem M. Oakeshotta ,nie zaczyna się wraz z rewolucją francuską ani wraz z przemianami przemysłowymi schyłku XVIII wieku; zaczyna się w tych powikłanych stuleciach, co do których, z powodu ich nieczytelności, żaden historyk nie potrafi rozstrzygnać, czy są podsumowaniem, czy wstępem - a mianowicie w XIV i XV wieku". Ta historia zaczyna się nie od powstania człowieka masowego, ale od pojawienia się człowieka indywidualnego w nowoczesnym sensie tego słowa. Por. M. Oakeshott, Masy $w$ demokracji przedstawicielskiej, thum. M. Szczubiałka, w: tegoż, Wieża Babel i inne eseje, Warszawa 1999, s. 147. 
krytycznego, umysłom zdesperowanym i biednym. Oświecenie inspirowane przez masy oznaczało ruch oddolny zawłaszczający cały porządek rzeczy - egalitaryzm oraz prawo do samostanowienia oparły się na wykluczeniu tych, którzy na mocy historii i sprawowanej władzy sami się wykluczyli - władza wraz z wykluczeniem kreuje długotrwałe oddzielenie oraz bunt. Kolejny raz masy przebiły się przez wydawałoby się, że dobrze już zarośnięta, pooświeceniową bliznę w XIX wieku, gdy ludzie wykorzystujący maszyny zaczęli wyrzucać „zbędnych” (sic!) ludzi na bruk, a tych, których nie wyrzucali, alienowali fizycznie oraz światopoglądowo ${ }^{4}$.

Rodzący się kapitalizm redefiniował różnice społeczne powodując, że jednym z fundamentalnych kryteriów definiujących masy stała się bezwzględna bieda, a wraz z nią cały ciąg społecznych, obyczajowych oraz politycznych konsekwencji. Formowanie się mas jest szczególnie wyraźnie obserwowane wtedy, gdy następuje zmiana form pracy, generowanych zysków oraz w konsekwencji tego także modeli funkcjonowania społeczeństw oraz sprawowania kontroli nad nimi. Rewolucja przemysłowa odsłoniła także jeszcze jedną charakterystykę mas - ukazała możliwość ich natychmiastowej reakcji zależnej właściwie także od stopnia ich zagęszczenia (np. w ośrodkach gospodarczych). Pojawiła się dialektyka wielości oraz zbędności - w szybkim tempie rosła potęga demograficzna mas ${ }^{5}$, co w połączeniu z ekspandującą technologią oraz $\mathrm{z}$ rozwijającą się biurokracją prowadziło do trwonienia na kolejnych polach bitewnych (w sensie militarnym oraz społecznym) potencjału ludzkiego. Epoka nowoczesna to epoka, która zaczęła w sposób systemowy traktować życie ludzkie oraz śmierć jako element zbędny ${ }^{6} . Z$ mas zaczęły wyłaniać się $m$.in. nowe podmioty reakcyjne-proletariat oraz ewoluujące wraz z nimi etosy działania.

Mniejszość albo mniejszości rzadko były oparte na uniwersalnych podstawach świata społecznego, na suwerennej i niepodważalnej aksjologii - zawsze żyły w oparciu o wiedzę i władzę ${ }^{7}$, którą dysponowały oraz ze względu na poczucie bezpiecznego oddzielenia od tych, którzy mogą niepokoić w czasie „zabaw i gier”. Masy od środka krystalizowały horyzonty oczekiwań i potrzeb, każde z pragnień na rewersie wypisane miało słowa: „bieda” albo „nędza”, albo „desperacja”, albo „gniew”, na awersie wyryte zaś było słowo „sprawiedliwość”, które mogło mieć różne synonimy: „my”, „nam”, ale

${ }^{4}$ G. Vattimo, Koniec nowoczesności, tłum. M. Surma-Gawłowska, wstęp M. Zawadzki, Kraków 2007, s. 25.

${ }^{5}$ José Ortega Y Gasset pisał o przyroście naturalnym w następujący sposób: „Już same te liczby wystarczą do wyjaśnienia naszej wizji współczesnej Europy, a nawet jeśli nie okażą się wystarczające, to w każdym razie pomogą nam do jej zrozumienia. Są to następujące dane: od wieku VI, kiedy to zaczyna się historia Europy, do roku 1800 - to znaczy przez dwanaście wieków - liczba ludności Europy nie zdołała przekroczyć 180 milionów. Natomiast w okresie od 1800 do 1914 - a zatem w nieco ponad sto lat - liczba ludności Europy wzrosła od 180 do 460 milionów! Uważam, iż porównywanie tych dwu liczb wystarczy, by rozproszyć wszelkie wattpliwości co do możliwości rozrodczych ubiegłego wieku”. J. O. Y Gasset, Bunt mas, tłum. P. Niklewicz, Warszawa 2004, s. 51.

6 Zdaniem Richarda L. Rubensteina zbędność ludzkiego życia stała się jednym z głównych czynników, które rozpędziły w XX wieku mechanizm Auschwitz. R. L. Rubenstein, The Cunning of History. The Holocaust and the American Future, Harper\&Row, New York 1978, s. XI.

7 M. Foucault, Nadzorować i karać. Narodziny więzienia, thum. T. Komendant, Warszawa 1998; M. Foucault, Wola wiedzy, w: tegoż, Historia seksualności, thum. B. Banasiak, T. Komendant, K. Matuszewski, wstęp T. Komendant, Warszawa 2000. 
też „nadzieja”, „poprawa”, ,przemiana”, „sens”. Te zależności odsłaniają ukrytą za nimi energię arbitralności wynikającą w dużej mierze z tego, że masy nie składają się z jednostek; wyłaniają się z , ,antyjednostek” zjednoczonych w nienawiści do indywidualności szukającej swych odbić w zwierciadłach akceptacji społeczeństwa, wyrażanej w jego przyzwoleniu na jej partycypację w normach, zasadach, obyczajach ${ }^{8}$.

\section{Propozycja, imagologia, imperium}

Michael Oakeshott pełen sceptycyzmu pisze, że współczesna sztuka polityki nie opiera się na „rządzeniu” rozumianym jako poszukiwanie najlepszych praktycznych rozwiązań konfliktów między jednostkami ani na utrzymywaniu poparcia dla takiej czy innej większości w zgromadzeniu ,,parlamentarnym”; jest ona raczej sztuką rozpoznawania tych propozycji, które mogą zmobilizować najwięcej głosów oraz takiego jej formułowania, że jej treść sprawiała będzie wrażenie, iż pochodzi od tych, do których jest adresowana 9 . Przestrzeń, w której rozpuszczają się ostatnie granice nowoczesności, wyznaczana jest, idąc za metaforą innego intelektualisty, Milana Kundery, przez imagologię, która doprowadza do tego, że ideologia przegrywa z imagologią. Przestrzenie reprezentacji, przedstawień oraz symulacji władzy neutralizują granice wytyczane przez państwa narodowe, co widoczne jest szczególnie $\mathrm{w}$ ich radzeniu sobie z problemami kulturowymi oraz ekonomicznymi; podział na to, co wewnętrzne oraz zewnętrzne ustalany jest m.in. poprzez zasięg funkcjonujących przekazów medialnych. Narodowe centra władzy ulegają atrofii. Ogólniejsze jeszcze konteksty ewolucji współczesnych państw i społeczeństw dotyczą zmian globalnych, które zapowiadają, zdaniem takich badaczy jak Michael Hardt oraz Antonio Negri, zmierzch suwerenności państw narodowych, co nie oznacza jeszcze zmierzchu władzy jako takiej. Zdaniem wyżej wspomnianych uczonych suwerenna władza przybiera nową postać, stając się układem narodowych i ponadnarodowych organizmów, złączonych wspólną logiką kontroli, określaną przez nich Imperium, które jest zdecentralizowanym i aterytorialnym aparatem rządzenia, obejmującym stopniowo całą ,globalną domenę"10.

\section{Dzialania mas}

Masy współcześnie pragną transcendować - poprzez nadawanie im złudnych omnipotencjalnych możliwości wyborczych oraz obywatelskich, ucieleśnianych niekiedy w postaci medialnych reprezentacji - aby zajać miejsce suwerena, społeczeństwa, państwa $^{11}$. Chcą wykorzystać nadwyżkę władzy, którą ich zdaniem posiadają, do tego, by

8 M. Oakeshott, Masy w demokracji przedstawicielskiej, op. cit., s. 156.

9 Ibidem, s. 163.

10 M. Hardt, A. Negri, Imperium, tłum. S. Ślusarski, A. Kołbaniuk, Warszawa 2005, s. 8-9.

11 Szymon Wróbel pisze, że „Nowoczesna suwerenność, przynajmniej od czasu Hobbesa, polega zasadniczo na transcendencji władcy, który będzie przyjmował postać - Księcia, Suwerena, ludu, państwa. Suweren jest w pewnym sensie nadwyżką władzy, służącą zabezpieczeniu ładu społecznego i jego stabilności, ładu organizowanego głównie poprzez formę państwa narodowego, zamkniętego 
uczynić ze świata zachodniego „utopię typu instant” realizowaną poprzez „,wertykalną inwazję barbarzyństwa"12.

Masy mogą współtworzyć lub współkonstytuować społeczeństwa, lub współistnieć w zjednoczonej Europie. Jeśli ich interesy są zbieżne $\mathrm{z}$ interesami podmiotów rządzących w UE, to masy usiłują funkcjonować jako społeczeństwa, a wtedy ich działania są konwergentne z polityką UE (porządek centryczny) oraz uznającymi tę strukturę społeczeństwami. Interesem UE jest także to, aby w jak największym stopniu jej strategie pokrywały się z oczekiwaniami społeczeństw oraz potencjalnie je dopełniających mas. Tym, co różni rządzących UE od mas, są definicje interesów oraz formy ich realizacji. Interesy wyznaczają także horyzont realnego ryzyka, które może doprowadzić do rozbicia współpracy między UE a społeczeństwami, wtedy ze społeczeństw mogą wyłonić się niezadowolone masy. Społeczeństwem jest taki podmiot zbiorowy, który akceptuje politykę rządzących UE oraz stara się wdrażać różne jej działania w swoim otoczeniu. Społeczeństwo może rozpaść się na masy lub stać się masa, gdy doświadczy zadowolenia z deprecjacji Inności, która dla danej zbiorowości może mieć implikacje negatywne albo pozytywne - w zależności od tego, czy zaakceptuje (afirmacja) lub odrzuci (antagonizm) ona politykę realizacji interesów przez rządzących UE. Społeczeństwo też może być niezadowolone z polityki rządzących lub ją popierać, jednakże różnica między masą i społeczeństwem jest taka, że społeczeństwo uznaje normy określające jego relację z rządzącymi w UE, natomiast masa nie musi, a często nie chce i nie umie tego uczynić. Masa może się stać społeczeństwem wtedy i tylko wtedy, gdy w zjednoczonej Europie będzie realizowała swoje interesy oraz rozwijała będzie w tym zakresie swoje kompetencje w ramach akceptowanych norm. Ten drugi warunek jest niemal niemożliwy do spełnienia z dwóch powodów: po pierwsze, implikuje on ciagłość w czasie, która nie charakteryzuje ewolucji mas oraz po drugie, masy opierają swą potęgę na ignorancji, której rozwój ma również charakter progresywny. Jeżeli jednak z jakiegoś powodu dojdzie do sytuacji, w której realizacja takich interesów zostanie zaprzestana, to doprowadzi to do stanu, w którym masa może stać się antagonistą społeczeństwa, a więc także tych wartości i zasad, które dane społeczeństwo uznaje za nadrzędne. Interesy mogą być ekonomiczne, polityczne, religijne, kulturowe, społeczne oraz etniczne. UE stara się uprawiać politykę, a więc konsekwentnie tworzyć praktyczne zastosowania dla norm, w celu możliwie najmniejszej szkodliwości w relacjach większości z mniejszościami.

Do XIX wieku bunt mas przybierał często postać rzeczywistych, fizycznych konfrontacji, w których rezultaty kontestacji doprowadzały do zmiany ustroju politycznego albo chociażby do nieodwracalnych zniszczeń. Wiek XX częściowo zachował tę możliwość (np. rewolucja z 1917 roku w Rosji), jednakże na skutek rozwijanej już w XIX wieku prasy i form komunikacji masowej, odsłonił nowe dziedziny aktywności mas: środki przekazu ${ }^{13}$ oraz ideologię konsumpcji.

na ograniczonym terenie, czy «pofałdowanej przestrzeni społecznej»”. P. Dybel, Sz. Wróbel, Granice polityczności: od polityki emancypacji do polityki życia, Warszawa 2008, s. 174.

12 J. O. Y Gasset, Bunt mas, op. cit., s. 54.

13 John Hartley stwierdził np., że nie byłoby demokracji amerykańskiej bez masowego, codziennego dziennikarstwa, które dostarczało bieżących informacji na różne tematy niemal w tym samym 
Interesy nie są granicą wyznaczająca jednoznaczne różnice między masami a rządzącymi. W kontekście rozwoju mediów masowych oraz wykształcenia się zmysłu umożliwiającego wyczuwanie nastrojów wśród mas, doszło do tego, że nie interesy, lecz sam ich odbiór określa akceptację lub odrzucenie realizowanej polityki. Paradoks współczesności polega na tym, że masy mają ambicje dotyczące ich społecznej oraz politycznej „transcendencji”, gdy w przypadku rządzących starających się rozpoznać oczekiwania większości i w ten sposób konstruujących najbardziej spodziewane formuły, prawa lub działania - główną ideą jest możliwość ,immanencji”, a więc upadania tego, co powszechne (często popularne, masowe) w to, co indywidualne, jednostkowe, średnie (w sensie przeciętne). Opozycję między tymi wymiarami, pozornie niwelującymi lub rozpuszczającymi różnice między wielością i jednością, wyznacza właśnie świat zapośredniczony w mediach masowych, jego wirtualny, w sensie alternatywny z możliwością zastąpienia elementu X przez element $\mathrm{Y}$ oraz prawdopodobny, byt.

Społeczeństwo w porozumieniu z rządzącymi działa integracyjnie. Różnica wyłaniająca się z ich działań wyrażana w postaci „,wektorów oddalenia mas” (masy oddalają się od integracyjnego centrum oraz mogą też oddalać się od siebie) działa dyspersyjnie. Społeczeństwo charakteryzuje się poprzez wolę tworzenia, masy zaś charakteryzują się poprzez wolę koordynacji. Perspektywa tworzenia opiera się na ciagłości projektu zmierzającego z przeszłości ku przyszłości poprzez teraźniejszość, zaś wola koordynowania opiera się na zasadzie czasu teraźniejszego, na realizacji tego, co doraźne. Tam dokąd sięga społeczeństwo, można więc mówić o istnieniu „przestrzeni obywatelskiej”, tam gdzie masy upajają się swą ,instant” aktywnością oraz omnipotencją, można mówić o granicy tej przestrzeni, dalej rozpościera się jedynie „przestrzeń wirtualna”. Masa z ciała jednostki czyni trampolinę własnych ambicji, oczekiwań oraz niespełnień, społeczeństwo nadaje temu ciału twarz, egzorcyzmując je z tego, co anonimowe, nawet za cenę biopolitycznych stygmatów wpisanych w to, co intymne, choć ciagle zawłaszczane przez systemy władzy. Masy ze względu na stosunek jednostek do wspólnych interesów narzucają tożsamość przynależności, tożsamość relacyjną (np. jeśli X nie może studiować, bo jego/jej na to nie stać, to jest to w mediach przedstawiane jako skutek polityki postkolonialnej. W tej perspektywie narzucona X-owi zostaje, jako jednostce, tożsamość przynależności do tej masy, którą definiuje podobna perspektywa). Tożsamość relacyjna opiera się na trwałym, choć nieciagłym procesie socjalizacji, z powodu którego możliwe staje się myślenie i działanie poprzez podobieństwa.

\section{Nomadyzm mas}

Masy są metaforyczne $\mathrm{w}$ tym sensie, że poprzez podobieństwo umożliwiają substytucję tego, co złożone i niewyartykułowane na miejsce tego, co trwałe i znane, dlatego tak często masy naśladują społeczeństwo - upodabniają się do niego. Społeczeństwo działa metonimicznie, a więc w oparciu o zasadę przyległości, przystawalności do norm, narzucanych przez rządzących, które warunkują centryczny porządek społecznej

czasie do coraz odleglejszych zakątków kraju. Por. J. Hartley, Popular Reality: Journalism, Modernity, Popular Culture, Arnold, London 1996, s. 32. 
ewolucji wzorców identyfikowanych jako integracyjne. Tożsamość przynależności odnajduje w jednostce to, co jest masowe; relacyjny wymiar tożsamości definiuje jej postawę w konkretnym działaniu. Jedną z charakterystyk mas w tym kontekście jest to, że tworzące je podmioty są nomadyczne. Oznacza to, że ich tożsamość przynależności oraz tożsamość relacyjna są płynne, a ich działania wpisują się w ogólne postmodernistyczne tendencje. Uśpienie i czuwanie - czyli działanie in potentia - są formami „przyczajenia się” mas w społeczeństwie. Masy koczują, obserwując wszelkie pęknięcia społeczne, których przyczyną mogą być różnice między rządzącymi a społeczeństwem albo różne, wielowariantowe przemieszczenia $w$ ich relacjach $\mathrm{z}$ innością, która i tak przez masy jest pojmowana arbitralnie - zawsze zaś mitycznie jako trwała, niemal interlokucyjna postać upodmiotowionego antagonizmu.

Nomada jest podmiotem, który można określić jako postmodernistyczny, industrialny, postkolonialny (w zależności od przyjmowanego stanowiska). „Jak długo podziały na klasę, rasę, tożsamość etniczną, płeć kulturową, wiek krzyżują się i wzajemnie oddziałują w konstytuowaniu podmiotowości, pojęcie nomady odnosi się do występowania wielu z nich jednocześnie" ${ }^{, 14}$. Masy są nomadyczne, co oznacza, że określa je łamanie konwencji i norm, „kłusowanie” na marginesach społeczeństw, państw oraz praw bez jednoznacznie określonej strategii i dającej się odczytać mapy. Nomadyczność oznacza więc stałą gotowość do łamania konwencji, jest jedną z zasadniczych sytuacji egzystencjalnych przekładających się na styl myślenia oraz poznawania ${ }^{15}$. Nomadyczność jest apriorycznie usankcjonowanym skutkiem wyboru ucieleśnionego w działaniu. Pojęcia wyboru oraz nomadyczności są nierozdzielne w horyzoncie refleksji odnoszącej się do mas i ich buntów.

Masy nie mają centrum - ideologicznego, kulturowego, językowego czy materialnego. Nie mają także autentycznej tożsamości - tę bowiem masy „działają”, „czynią”, wyrabiaja poprzez walkę o interesy. Brak stałego aksjologicznego centrum, a także założenie, że masy karmią się owocami „kulturowego kłącza”, jest niewątpliwie skutkiem oddziaływania na nie mediów i kultury popularnej, w kontekście której te przekazy medialne i style konstruujące ich narracje określają to, co w danym momencie może zostać potraktowane jako ważne (arbitralnie ustalone przez nadawców i odbiorców), bieżące, tymczasowe, jako „umowne” wreszcie centrum teraźniejszego świata.

\section{Klasa nie-Suwerenna}

Pierwszy raz właśnie w XX i XXI wieku masy znajdują w zbiorze interesów charakterystykę etniczności jako jedną z tak samo ważnych, jak religijne czy społeczne. Kategoria etniczności ma w tym wymiarze także kontekst postkolonialny, gdyż powstają nowe przestrzenie „wyobcowania zawłaszczającego”, które wewnątrz np. dawnych krajów kolonialnych (imperiów) gromadzą duże grupy ludzi ubogich, emigrantów z byłych terenów kolonialnych, którzy rekonstruują swoje wspólnoty w polu na-

14 R. Braidotti, Podmioty nomadyczne. Ucieleśnienie i różnica seksualna w feminizmie współczesnym, tłum. A. Derra, Warszawa 2009, s. 27.

15 Ibidem, s. 23. 
leżącym do byłego „zdobywcy”. Parafrazując w tym miejscu autorów książki Imperium można więc zauważyć, że w ramach państw europejskich przemieszczeniu ulega podział przestrzenny trzech światów - Pierwszego, Drugiego i Trzeciego - tak że odnajdujemy nieustannie elementy Pierwszego w Trzecim Świecie, Trzeciego w Pierwszym, a Drugiego już niemal nigdzie ${ }^{16}$. Zjednoczona Europa z jednej strony zmuszona jest odpowiadać na mechanizmy, które tworzą zarówno udogodnienia, jak i przeszkody w całym systemie światowych relacji, z drugiej jednak strony od środka boryka się m.in. z buntami mas, które na skutek głównie przemian gospodarczych będą coraz częściej starały się, upodobniając się do społeczeństwa, wywalczyć swój kapitał. W ten sposób może dochodzić do coraz drastyczniejszych reakcji ze strony rządzących Unią Europejską oraz do coraz bardziej antagonistycznych zachowań ze strony mas. Taki podział - wskazujący na ilościową przewagę mas nad mniejszością rządzących oraz nieustannie rozdarte społeczeństwo (społeczeństwa) może prowadzić do tego, że powtarzał się będzie schemat, o którym pisał Ortega Y Gasset, a mianowicie, że większość, masa, będzie chciała tego, co posiada mniejszość - taka tendencja nie tylko będzie ewentualnie zacierać różnice w sprawowaniu władzy, ale także będzie domagała się spełnienia ambicji chcących zawłaszczyć możliwości dystrybucji kapitału; taka tendencja, mająca własności środków wybuchowych umożliwiających projektowanie postaw rewolucyjnych, jest w dłuższej perspektywie ostatecznością bez odpowiedzialności.

Zmiana systemu społecznego doprowadzi do dyspersji, lecz za skutki tej dyspersji nikt nie będzie odpowiadał, dlatego właśnie, że masa działa pod szyldem anonimowości, a rządzący kryją się za szańcami biurokracji oraz symulacji. Współczesna opozycja „masa : władza”, która wyznacza umowne ramy definiujące Unię Europejską ze względu na jej tendencje centralistyczne (jako jeden z przejawów polityki wewnętrznej) oraz decentryczne (jako jeden z przejawów konfrontacji z tym, co zewnętrzne) nie jest historyczna ani dialektyczna, wyznacza ona raczej pole aproksymacji nadużyć, w obszarze którego rejestrować można każdą zmianę motywowaną ekonomicznie, politycznie oraz kulturowo.

Zjednoczona Europa nie udźwignie mas od środka, gdyż coraz częściej przypomina Pascalowowego człowieka, którego ogarnia podwójna nieskończoność - nieskończoność wielkości, nieskończoność tego, co zewnętrzne (procesy światowe, w których UE jest tylko jednym z depozytariuszy prawa głosu i możliwości działania, globalnym aktorem $^{17}$ ) oraz nieskończoność małości, nieskończoność tego, co wewnętrzne (procesy zachodzące wewnątrz struktur UE, rozpadające się ciągle na partykularyzmy, których horyzont przestrzenny jest bardzo wyraźnie określony, a czasowy odnosi się do tego, co bieżące i nagłe). Jeśli uwzględni się np. interesy etniczne w perspektywie nieskończenie wewnętrznej, to masy działają w następujący sposób: masy składające się z różnorodnych grup etnicznych artykułują się, manifestują się wg wzorców emancypacyjnych, które powstały w zachodnich społeczeństwach pooświeceniowych, negując porządek, w którym funkcjonują.

16 M. Hardt, A. Negri, Imperium, op. cit., s. 9.

17 Ch. Bretherton, J. Vogler, The European Union As a Global Actor, Taylor \& Francis Routledge 2006, s. 37-62. 
Oto jest paradoks wyczerpywanej od środka, nieskończenie wewnętrznej zjednoczonej Europy. Przykładem na tę aporię emancypacyjnej samoświadomej jednostki jest to, że masa w imieniu jednostki, a właściwie jej kosztem, dąży do wyzwolenia całości bez jednoznacznego programu, który w perspektywie długofalowej rozwiązałby problemy natury społecznej. Społeczeństwo chce rozwikłać problem, masy chcą zamanifestować swój sprzeciw, skutkiem tego na przykład w przestrzeni fizycznej miasta dochodzi do zniszczeń (np. przedmieścia Paryża oraz innych miast francuskich, które stały się dziedziną zniszczenia w listopadzie 2005 roku; media podały ${ }^{18}$, że bezpośrednią przyczyną tych wydarzeń była śmierć dwóch nastolatków pochodzenia afrykańskiego [ang. African origin], którzy ukrywając się przed kontrolą policyjną, schowali się w stacji transformatorowej, gdzie zostali porażeni prądem, pośrednią zaś przyczyną miała być nieskuteczna polityka imigracyjna francuskiego rządu), ale także do atomizacji przestrzeni miejskiej (masy mają odmienne pochodzenie społeczne, tożsamościowe, religię, muzykę - czujne macki buntu opartego na manifestowanej własnej odmienności). W 2008 roku ukazał się francuski film Entre les murs w reżyserii Laurenta Canteta ${ }^{19}$ ukazujący tło napięć społecznych wynikających z trudnych do zredukowania różnic etnicznych, religijnych oraz kulturowych. Fatalistyczna wymowa tego dzieła, która nie jest wyartykułowana wprost, przejawia się w tym, że bohaterowie tego filmu - uczniowie pochodzący z rodzin afrykańskich, chińskich oraz arabskich - wykorzystują język francuski (figura nowej tożsamości oraz samoprezentacji w kulturze potoczności) do wyrażania różnic (własnej tożsamości oraz siebie jako odmienności). Używany przez uczniów język jest bowiem narzędziem władzy suwerena, dlatego nie chcą oni w nim zamieszkać (symbolicznego wymiaru nabierają sceny, w których uczniowie buntują się przeciwko uczeniu się gramatyki języka francuskiego oraz, kiedy ich rodzice nie mogą porozumieć się z francuskimi nauczycielami w języku „urzędowym") ani dać się poskromić wiedzy i władzy funkcjonujących poprzez relacje między znaczonym i znaczącym. Masy w jednoczącej się Europie zyskują swą siłę między innymi poprzez to, że składają się w dużej mierze z takich właśnie klas nie-Suwerennych, a więc świadomej siebie inności, która w dostępnych kodach (np. język albo miejska przestrzeń symboli i znaczeń) wyraża własną możliwość potencjalnie destruktywnej społecznie reakcji.

Aporie opisywane powyżej widać szczególnie na niwie wzrastającej liczby osób bezrobotnych w zjednoczonej Europie oraz konfliktów motywowanych społecznie, etnicznie i/lub religijnie. Dla przykładowego zobrazowania takich sytuacji można posłużyć się opisem swoistego paradoksu, który polega na tym, że wielu obywateli tureckich mieszkających w Niemczech nie chce asymilować się ze społeczeństwem niemieckim. Taka postawa powoduje, że ich tożsamość relacyjna i - w tej perspektywie - możliwość afirmacji własnego społeczno-językowo-kulturowego zakorzenienia w Niemczech zależą od traktowania przez społeczeństwo niemieckie polityki oraz obyczajów tureckich, ale także, co równie istotne, zasad i norm opartych na islamie.

18 Por. Many held as French riots spread, http://news.bbc.co.uk/2/hi/europe/4407688.stm (10.09.2009). Skalę zniszczeń można zobrazować na przykładzie ilości spalonych jednego dnia, tj. 5.11.2005, samochodów - zniszczono w ten sposób około 900 aut.

19 Entre les murs, pol. thum. Klasa, reż. L. Cantet, Francja 2008. 
W przenośni można tę sytuację opisać następująco: przedstawiciel mniejszości, który nie asymiluje się ze społeczeństwem niemieckim, zaczyna budować swą tożsamość nie tyle wokół pojęcia narodu czy grupy etnicznej, ale na przykład poprzez swą identyfikację religijną. Taka perspektywa jest możliwa, gdy człowiek wyobcowany (wykorzeniony politycznie albo społecznie) zaczyna poszukiwać w niepewnym dla siebie czasie czegoś bezwzględnie trwałego, nawet jeśli fundamenty tego mają swoje źródło w tym, co symboliczne. Religia jest w tym kontekście bastionem trwałości oraz ramą przynależności poprzez rytuał modlitw do wspólnoty (tworzonej z innymi wiernymi, których nie obowiązują granice polityczne państw) realizowanej poprzez nią aksjologii (wartości i zasady postępowania według nich), wreszcie niewysławialnej, a wciąż od nowa przeżywanej, sfery sacrum.

Paradoks ten jest o tyle też istotny, że mniejszość turecka w Niemczech, a konkretnie ta jej część, która nie chce się asymilować, nie uwzględnia przy tym nawet ambicji politycznej Turcji wynikającej z chęci wstapienia tego kraju do wspólnoty UE. Osoby takie nie są zainteresowane integrowaniem się ze społeczeństwem niemieckim, często zaś bardziej interesuje je los zabijanych muzułmanów w Iraku czy Palestynie, krytycznie oceniają także działania wojsk niemieckich w Afganistanie. Zdaniem Guido Steinberga, doradcy ds. terroryzmu w rządzie Gerharda Schrödera, Niemcy unikają publicznych dyskusji na temat problemów wynikających z asymilacji mniejszości tureckiej, choć obawiają się jej skutków. W Niemczech żyje mniej więcej około dwa miliony siedemset tysięcy Turków, co powoduje, zdaniem Steinberga, że społeczne skutki kłopotów z asymilacją mogą być źródłem różnych form ekstremizmów, co ciekawe - niekoniecznie w ośrodkach będących enklawami mniejszości tureckiej, ale właśnie w zwyczajnych miastach, jak np. w Langen niedaleko Frankfurtu, gdzie dorastał Adem Yilmaz, 28-letni Turek (który później przeszedł szkolenia w obozach dla terrorystów w Pakistanie; został schwytany jako jedna z osób przygotowujących zamach ${ }^{20}$ ).

W 2006 roku w raporcie przygotowanym przez niemieckie służby wywiadowcze, jak podają Mark Lander oraz Nicholas Kulish z „The New York Times”, w Niemczech miało przebywać około trzydzieści dwa tysiące sto pięćdziesiąt osób, które przejawiało tendencje ekstremistyczne, z czego aż dwadzieścia siedem tysięcy dwieście pięćdziesiąt osób miało tureckie pochodzenie, ale tylko mała część tej grupy, mniej nawet niż sto osób było postrzegane jako osoby naprawdę niebezpieczne, dlatego też były pod stałą obserwacją ${ }^{21}$. Konsekwencją niemieckich porażek wynikających z nieudanej, zdaniem autorów omawianego artykułu, polityki integrującej mniejszość turecką ze społeczeństwem niemieckim jest rosnąca liczba osób, które nie wykazują żadnego zainteresowania tym, co dzieje się w głównym nurcie tego społeczeństwa. Brak zainteresowania ma przynajmniej dwa aspekty - pierwszy, rosnąca masa nieasymilującej się mniejszości tureckiej może działać dyspersyjnie na społeczeństwo niemieckie oraz drugi, ze społeczeństwa niemieckiego mogą się wykształcić masy, które będą działały destrukcyjnie na mniejszość turecką w Niemczech. W pierwszym przypadku ,innym”

${ }^{20}$ M. Lander, N. Kulish, Arrest of One Turk in Germany Brings New Scrutiny to a Society of 2.7 Million, (tekst opublikowany 8 września 2007 r.), http://www.nytimes.com/2007/09/08/world/europe/08germany.html (6.10.2009).

21 Ibidem. 
jest społeczeństwo, w drugim ,innym” jest masa - w obydwu tych ujęciach „inność” jest nieustannie żywą raną. W pierwszym przypadku działanie mas (niechcących lub niezdolnych do asymilacji) może być spowodowane postawą rządzących wobec np. ich ingerencji w sferę rytualno-obyczajową mniejszości muzułmańskiej. W drugim przypadku brak pracy doskwierający Niemcom lub - jak to miało miejsce w Neapolu w reakcji Włochów wobec Romów - puszczona pogłoska w połączeniu z jakąś formą narastającego konfliktu między tak odmiennymi zbiorowościami, może doprowadzić do niebezpiecznego buntu mas, których działania wymierzone będą przeciwko mniejszości tureckiej ${ }^{22}$.

\section{Rozkoszne okrucieństwo}

Masy mogą ze względu na możliwość aktywności politycznej być podstawą rozwoju reżimu totalitarnego. Jego spektakl może się jednak składać z podmiotów, które nie tyle nawet chcą stworzyć organizację polityczną, co usiłują wytworzyć rodzaj wspólnoty politycznej ugruntowanej w osądzie estetycznym. Pojawia się u nich rozkosz na widok okrucieństwa oraz na skutek osądu oceniającego w trybie natychmiastowym wartość jednostkowego życia. Mas nie spaja w tej perspektywie świadomość wspólnoty interesów, bo brakuje im wyraźnej przynależności klasowej. Masy łączy upojenie, ale i upojony spektaklem lud osądza przedmiot swego upojenia ${ }^{23}$. Powyższe interpretacje wpisują się w rozważania oparte na analizie korzeni totalitaryzmu. Masy zmieniają jednak w perspektywie wcześniej opisanych aspektów swoją zasadę samoorganizowania oraz samoporządkowania. Pojawiają się interesy - motywowane poprzez określone konteksty - które nie wynikają z przynależności klasowej, na miejsce świadomości braku tego rodzaju przynależności pojawiły się bowiem nowe ramy (przyczyny) modelujące możliwość organizowania się mas oraz ich wyodrębniania się. Jeśli więc Hannah Arendt, pisząc o korzeniach totalitaryzmu, wskazywała na to, że termin „masy” ma zastosowanie wszędzie tam, gdzie ludzie, którzy, ze względu na ich wielką liczbę albo bierność, albo poprzez połączenie obu tych kryteriów nie mogą stworzyć organizacji opierającej się wspólnocie interesów ${ }^{24}$. Jeśli zgodzimy się, że dwiema istotnymi charakterystykami mas jest ich liczba oraz bierność, to należy uwzględnić, że w kontekście możliwych buntów mas pojęcia ta wymagają zredefiniowania. Liczba może być określona ze względu na kryterium identyfikacji, można nawet powiedzieć kim jest liczba, a ta perspektywa może wręcz naszkicować albo projektować możliwy rozmiar oddziaływania danej masy. Liczba jest więc umotywowana kontekstem społecznym, politycznym, religijnym, językowym oraz kulturowym, jej wartość określa charakter buntu. Bierność polityczna mas przestaje charakteryzować tak złożony podmiot.

Masy poszukują satysfakcji, o tyle też niekoniecznie aktywność polityczna może wyznaczać ich horyzont działania. Masy współcześnie nie są bierne. Artykułują swoje

22 Ibidem.

23 Por. P. Dybel, Sz. Wróbel, Granice polityczności, op. cit., s. 178.

24 Por. H. Arendt, Korzenie totalitaryzmu, tłum. M. Szawiel, D. Grinberg, t. I, Warszawa 1989, s. 126. Cyt. za: P. Dybel, Sz. Wróbel, Granice polityczności, op. cit., s. 178. 
ambicje poprzez media, które mogą być przez nie współtworzone, ale także poprzez to, że w polityce zmieniło się bardzo dużo - mogą ich działania stawać się treścią kultury potoczności. Ten mechanizm polega na tym, że, jak to wnikliwie opisywał Michael Oakeshott, zaczyna się liczyć to, co wirtualne, a co odzwierciedla dominujące tendencje i w tej perspektywie wymusza konkretne postawy i decyzje ${ }^{25}$. Masy współcześnie nie muszą więc używać siły w tradycyjnym sensie, aby wyartykułować swój bunt, czasami wystarczy tylko ruch na „pofałdowanej mapie społecznej”. Masy mogą bowiem łączyć żywioł wypróbowany wcześniej z tym, co najlepiej oddaje potęgę rzeczywistości prawdopodobnej, którą warunkują sondaże oraz słupki popularności z jednej strony, a także wszystkie dostępne poprzez nowe media sposoby wyrażania i manifestowania buntu. Jeśli więc media masowe pokazują zamieszki na przedmieściach Paryża, to nie tylko obrazują rzeczywiste zdarzenia, ale także - i tu jest widoczna - prewencyjna moc buntu albo wielkie prawdopodobieństwo jego zaistnienia - roznoszą bunt potencjalnie projektując kolejne jego formy, infekując masy jeszcze uśpione (różnica interesów!), ale gotowe na wypadek zbieżności interesów zbuntować się realnie przekraczając wirtualne ramy medialnego przedstawienia.

\section{Media mas}

Masom w ich buncie wystarczy więc czasami estetyczna satysfakcja, a tej dostarczają medialne obrazy; dlatego też tak ważna we współczesnej zachodniej cywilizacji jest figura kozła ofiarnego, która stanowi jedynie substytut społeczno-politycznej odpowiedzialności m.in. rządzących za podejmowane przez nich działania. Masy są mimetycznie nienasycone - chcą praw właściwych dla społeczeństwa, ale jednocześnie wykorzystują swoją prawdopodobną moc (niedającą się zmierzyć, oszacować ani nigdy w pełni zrealizować) do tego, by naśladować władzę. Chcą rozkoszy obywatelskiej rozdzielanej „sprawiedliwie” przez siebie nie dbając przy tym o żadną racjonalność. Media pierwsze pokrapiają krwią z kozła ofiarnego ekrany telewizyjne i słupki reakcji „społecznej”, tzw. opinii publicznej. Kiedy ofiara zostaje spełniona, można oczyścić się z winy w oczekiwaniu na kolejnego kozła ofiarnego (zamieszki na przedmieściach Paryża miały swój symboliczny początek w reakcji na śmierć dwóch młodzieńców, którzy stali się „ofiarami” systemu władzy; zachowanie mas w Neapolu miało swą symboliczną „ofiarę” w osobie ukradzionego przez rumuńską Romkę dziecka). Kozłem ofiarnym może być jednostka, zbiorowość, ale także jakiś dokument, zarządzenie. Masy muszą w warstwie symbolicznej znaleźć ofiarę, która ich działaniom nadaje sens. Figura kozła ofiarnego nie jest logiczna. Jeśli ginie $\mathrm{X}$ będący reprezentantem jakiejś mniejszości, to nagle okazuje się, że staje się on kozłem ofiarnym tej mniejszości, która szybko przechodzi w masę. Następnie dochodzi do buntu, czasami dosłownego, jak to miało miejsce na przedmieściach Paryża. W odpowiedzi rządzący znajdują kozła ofiarnego, aby ten bunt zażegnać. Masy nie pytają o to, dlaczego X stał się ofiarą - np. otoczenia, w którym wzrastał, wychowania, braku perspektyw itp. Masy sądza, a ich sądy stają się faktami, na które częstą reakcją jest czyn rządzących albo działanie sa-

25 M. Oakeshott, Masy w demokracji przedstawicielskiej, op. cit., s. 153-165. 
mych mas. Siłą mas jest więc niedyskursywność. Masy potrzebują symbolu, który w tej mimetycznej kakofonii staje się protezą ideologii, samoorganizując się doznają satysfakcji, gdy widzą rezultaty swych reakcji, a potem powtórzenia tych rezultatów. Masy są jednak uśpionym golemem, który - jak w praskiej legendzie - może zostać ożywiony jednym zaklęciem - na miejsce met (nieżywy) może pojawić się emet (ożywiony). Golem powstaje, masy się buntują. Wystarczy określenie zagrożenia jakiegoś istotnego interesu ( $m e t$ - na przykład postępująca pauperyzacja, nieposzanowanie religijnych obyczajów), aby natychmiast uformowała się doraźna często, definiowana tylko częściowo tymi samymi interesami, masa (emet). Największą siłą mas jest ich stan gotowości do działania, stan uśpienia, możliwości buntu - w tę wirtualną pułapkę wpadają rządzący oraz społeczeństwa. Ten stan uśpienia wyznacza właśnie horyzont możliwości rozpoznania przez rządzących określonych potrzeb mas, aby w perspektywie tego jak najwięcej z jednostek identyfikowało się ze społeczeństwem. Paradoks takiego stanu polega więc na tym, że uśpione, potencjalnie aktywne masy stają się natychmiast reaktywne, działają bezpośrednio i nagle.

Społeczeństwo informacyjne, w którym dostęp do informacji oraz jej tworzenie i przekaz wyznaczają prawdziwą cenę codzienności (ale także rozmiar przeciętności jej użytkowników oraz konsumentów) prowadzi do tego, że w cenie - politycznej oraz społecznej - jest to, co staje się niepowtarzalne, dotyczy to także wykonywanych zawodów. Digitalizacja wielu dziedzin gospodarki, polityki i kultury wymaga od mas tego, by nadążały za wymaganiami technologicznymi, aby się rozwijały proporcjonalnie szybko i skutecznie względem tego, czego wymaga rynek pracy oraz codzienne uczestniczenie w medialnej, kakofonicznej rzeczywistości. Zjawisko redystrybucji pracy ma wymiar globalny, co powoduje, że głównie państwa rozwijające się dostarczają nisko opłacanej nieopodatkowanej produkcji. Przejście od produkcji przemysłowej do usług i struktur opartych na informacji powoduje ,zanikanie tradycyjnych społeczno-symbolicznych systemów opartych na państwie, rodzinie i męskim autorytecie" ${ }^{26}$.

Jean Delumeau pisał, że bunty nie były w historii Europy tak śmiercionośne jak epidemie, ale swoją nagłą gwałtownością wybijały rytm zbiorowego niepokoju, który „między jednym a drugim wybuchem trwał milczący lub utajony”27. Między 1590 a 1715 r. wybuchło w Akwitanii od 450 do 500 buntów ludowych (w najszerszym rozumieniu tego słowa, przy założeniu Yvesa-Marie Bercé’a, że uformowały się uzbrojone oddziały skupiające uczestników przybyłych z kilku wspólnot wiejskich i trwały w gotowości więcej niż jeden dzień). We Francji, w XVIII wieku - wyłączając rewolucję 1789-1799 r. doszło mniej więcej do około stu zamieszek między 1715 a 1787 r., zaś na wsi angielskiej między 1735 a 1800 rokiem doszło do około 275 buntów. Jean Delumeau pisze, że w cywilizacji Europy preindustrialnej można - w przenośni - mówić o „codzienności rewolty"28.

26 R. Braidotti, Podmioty nomadyczne. Ucieleśnienie i różnica seksualna w feminizmie wspótczesnym, thum. A. Derra, Warszawa 2009, s. 24-25.

${ }_{27}$ J. Delumeau, Strach w kulturze Zachodu (XIV-XVIII w.), thum. A. Szymanowski, Warszawa 1986, s. 137.

28 Ibidem, s. 137. 
Francuskiego uczonego interesowała rola strachu w buntach epoki preindustrialnej, który wzmacniał reakcję thumu zbierającego się bez określonego celu oraz wchłaniającego pogłoski, potęgujące przestrzeń jego oddziaływania, której azymutami stawały się ataki na pewne osoby; tłum plądrował i grabił. Ta perspektywa jest jednym ze źródeł możliwych oraz realizowanych buntów mas we współczesnej Europie. Rozwijała się ona jakby na marginesie tego, co zapowiadało już formy kontestacji typu nowoczesnego. W XVIII wieku, np. w Lyonie, robotnicy przemysłu jedwabniczego nie buntowali się w czasach głodu lub bezrobocia. Do zorganizowanych wystapień, zwłaszcza w 1744 i 1786 r. dochodziło w okresach zapewnionej pracy i względnego prosperowania, kiedy ich życiu i życiu ich rodzin nic nie zagrażało ${ }^{29}$. Te dwa modele odsłaniały przepaść między plebsem miejskim i wiejskim a wszystkimi warstwami burżuazji. Jean Delumeau pisze o okresie rewolucji, kiedy to obok całkowicie „magicznych”, irracjonalnych, budowanych na marzeniu o złotym wieku oraz czci dla ,świętej gilotyny", która została ,wyniesiona do rangi błogosławionego posagu obnoszonego po ulicach", miały miejsce taktyczne, oparte na zamierzeniach politycznych, bunty, które odzwierciedlały zmysł organizacyjny inspirujących je podmiotów. Pęknięcie między tymi dwoma światami zdaje się przechodzić przez własność prywatną. „Wszystko odbywa się tak, jakby posiadanie minimum zabezpieczenia ekonomicznego było warunkiem koniecznym efektywnej racjonalizacji posunięć politycznych"30.

Te dwa modele są niewątpliwie źródłem współczesnych buntów, które z jednej strony mogą wybuchać nagle, irracjonalnie, doraźnie tworząc tymczasowe, relacyjnie tożsame zbiorowości albo mogą być społeczną reakcją na np. politykę oszczędności państwa, a wtedy stają się taktyczną grą, którą rozgrywa się często w sposób racjonalny i uporządkowany. Istotne jest jednak to, że od XVIII wieku wyłaniają się dwie zasadnicze tendencje, które do współczesności będą znajdowały swoją inkarnację.

Druga połowa wieku XX oraz początek XXI wieku pokazał, że nie jest tak, iż podstawą zachowań mas (i społeczeństwa) jest posiadanie minimum zabezpieczenia ekonomicznego ${ }^{31}$. To minimum może być społecznym tłem buntu. Często asumpt do wybuchów - i tu eufemizm rządzących: „rozruchów”, które wyłaniają się w oparciu o irracjonalne przesłanki, które autopoietycznie nabierają treści religijnych, etnicznych, obyczajowych, materialno-bytowych dają przecież przekazy medialne albo tylko pogłoski wybuchające na chłonnym gruncie uprzedzeń, niepewności oraz strachu.

Tydzień przed posiedzeniem nowego rządu Silvio Berlusconiego, które odbyło się w Neapolu, na peryferiach tego miasta, w dzielnicy biedoty Ponticelli, odbyło się „czyszczenie, w innych częściach świata zwane «etnicznym». Rozwścieczony thum obrzucał kamieniami i butelkami z benzyną cygańskie obozowisko, zamieszkane w większości przez Romów z Rumunii, a najczęściej powtarzany okrzyk brzmiał: «Spalimy ich żywcem!». Iskrą do ataku stała się wieść o próbie porwania sześciomiesięcznego włoskiego niemowlęcia przez 16-letnią Romkę. Niedługo potem prymitywne budy z blachy i kartonu stały w ogniu. Ośmiuset Romów uciekło w popłochu

29 Ibidem, s. 138.

30 Ibidem, s. 138.

31 Por. F. Turner, From counterculture to cyberculture: Stewart Brand, the Whole Earth Network, and the rise of digital utopianism, The University of Chicago Press, Chicago-London 2006. 
z Ponticelli”32. Opisane zdarzenie oparło się na pogłosce, choć na pewno było ono skutkiem narastającego konfliktu oraz napięcia, którego nie rozładowały w odpowiednim czasie właściwe instytucje. Autor zacytowanego artykułu pisze o ,antyimigranckiej obsesji”, która przykrywa głębsze unijne niepokoje. Zdarzenie w Neapolu wynikało w dużej mierze ze strachu przed ucieleśnioną innością - w tym konkretnym zdarzeniu Romami z Rumunii, ale także przed tym wszystkim, co ta „inność” ucieleśniała - głównie biedę i przestępczość. Można jednak zauważyć, że ta nagła (perspektywa widza śledzącego przekaz medialny, który nie śledzi narastającego napięcia) reakcja wyraziła lęk mas przed tym, co może stać się ich własnym losem, w którym „budy z blachy i kartonu" mogą być makietą nie tyle cudzej, co murem własnej biedy.

Romowie w tym zdarzeniu mogą być traktowani jako kozioł ofiarny na dwa sposoby. Pierwsze ujęcie właściwie pokazuje, że są oni innością, która musi być wykluczona, bo jest źródłem tych aberracji, które stawać się mogą udziałem innych grup etnicznych czy narodowych albo tych zdarzeń, w których ofiarami mogą się stać obywatele włoscy (co jest szczególnie istotne, gdy uwzględni się fakt, że bezpośrednią przyczyną tego pogromu była pogłoska o próbie ukradzenia przez romską kobietę małego dziecka). Są oni w tej perspektywie źródłem zagrożenia. Drugie ujęcie, pokazuje, że tłum zaatakował w ten sposób pośrednio przez Romów władzę, której polityka prowadzi do tak złożonych społecznie problemów (przestępczość, bieda, prostytucja, bezrobocie, zanieczyszczenie środowiska i przestrzeni miejskiej). Tłumy potrzebowały jednak innego kozła ofiarnego (rzekomo uprowadzone dziecko włoskie), który w przestrzeni symbolicznej uzasadniłby zakres i cel ich działań.

Romowie ponieśli ofiarę, aby w ten sposób uaktywnić reakcję rządzących: aresztowano w całym kraju wiele osób pochodzących głównie z Rumunii oraz Maghrebu podejrzanych o handel narkotykami, rozboje, kradzieże oraz sutenerstwo, ponad 118 nielegalnie przebywających we Włoszech dostało nakaz natychmiastowego opuszczenia kraju ${ }^{33}$.

Masa jest aktywna, bo swą twarz rozbija w lustrze anonimowości, której ramiona sięgają wszędzie tam, gdzie inność odsłania swoje oblicze. To metaforyczne ujęcie ukazuje arbitralność decyzji podejmowanych przez masy. Mają one ambicje, by stać się tym, kim nie są w ich mniemaniu rządzący - władzą skuteczna, która przekracza sens działania wg określonych, demokratycznych norm. Rządzący muszą więc pokazać, broniąc porządku oraz swojego własnego status quo, że to właśnie normy oraz prawa są bezwzględnie skuteczne, że nie jest potrzebna reakcja mas roszcząca sobie prawo do bycia ich substytutem.

Niemal każda odpowiedź władz na skutki wydarzeń, których przyczyną są działania mas, jest więc legitymizacją ich prawa do rządzenia; jest także braniem w nawias mas. Działania rządzących mają przekonać masy, że społeczne oraz polityczne instytucje są nie do zastapienia, dlatego tak ważna jest figura kozła ofiarnego oraz opowieść o niej (czemu służą oczywiście przekazy medialne). Siłą mas jest ich strach, dlatego też książka Jeana Delemeau jest wciąż zdumiewająco aktualna, choć pojawiają się nowe wymiary tego, co rodzi lęk, a także kto i co go ucieleśnia oraz jak reprezentuje. Wspól-

32 Cyt. za: W. Kedaj, Strachy Europy, http://www.wprost.pl/ar/130888/Strachy-Europy/ (3.10.2009).

33 Ibidem. 
nym elementem dla tych dwóch interpretacji kozła ofiarnego jest jednak to, że musi być poniesiona ofiara, która na skutek chwilowego zakłócenia porząaku - przywraca jego oczekiwany wymiar, dając w ten sposób upust kumulującej się energii buntu; stan taki nie ma jednak wymiaru ,społecznego eschatonu”, dlatego jest głównie stanem hibernacji (w zależności od przyczyn: politycznej, kulturowej, religijnej itp.).

Społeczeństwo chce działać taktycznie, reakcją mas jest myślenie magiczne, w którym relacje przyczynowo-skutkowe wzięte są w nawias lub zwyczajnie niepotrzebne. Masy mogą uwodzić społeczeństwo oraz rządzących przy wykorzystaniu reprezentacji własnych reakcji. Oglądając przekazy telewizyjne z różnych zamieszek (kolejny eufemizm) widz może dojść do wniosku, że właściwie trudno określić sprawcę i ofiarę, trudno zrozumieć często o co chodzi i kto ma ponosić odpowiedzialność za zachodzące zdarzenia. Widz, uzbrojony w wygodny fotel, może więc sądzić, że tym wszystkim rządzi totalny absurd, jakaś niewidzialna siła, a częstotliwość relacji medialnych dokonuje za niego nadania znaczenia zdarzeniom, a więc, jeśli temat ginie $\mathrm{z}$ wiadomości, znaczy to, że bunt minął; telewizja pokazała - sprawa zakończona. Widz nie dostrzega tego, że bunt jest reakcją na przyczynę, która znajduje się poza nim, a więc, że problem dotyczy nie tylko ram widowiska, ale często identyfikacji fundamentów trwania jakiejś zbiorowości. Zupełnie inne stanowisko prezentuje ktoś, kto jest blisko „irracjonalnego chaosu", ten (lub ta) chce jak najszybszej reakcji rządzących, bunt jako widowisko widziane w „trójwymiarze” wywołuje strach oraz projektuje ewentualny obraz ofiary. Współczesny bunt mas w zjednoczonej Europie jest więc zależny od identyfikacji z płynnie dobieranymi interesami, ale także z dużą atomizacją zbiorowości. Aby dobrze tę właściwość zobrazować, należy wskazać na to, że widz oglądający jakąs formę buntu - mas lub społeczeństwa, a więc chaotyczną, nieokiełznaną albo zaprogramowaną - ze względu na pozornie stałą identyfikację z jakąś grupą społeczną może dystansować się lub angażować się w to, co widzi jako reprezentację buntu.

W Polsce w ostatnich latach brakuje manifestacji niezadowolenia, które byłyby wyrazem sprzeciwu wspólnego dla różnych grup zawodowych, społecznych oraz wiekowych, choć nie przeszkadza to w działaniu mas. „Człowiek masowy”, jak ciekawie zauważył Michael Oakeshott, jest „określony przez charakter, a nie przez liczebność" 34 . Widz, który jest dla przykładu robotnikiem budowlanym albo lekarzem, ogląda w telewizji protest pielęgniarek i odnosi wrażenie, że nie dotyczy go sprawa, z powodu której doszło do tego protestu, choć jest gotowy do reakcji ,na wszelki wypadek", jest wygodny i poddańczy wobec systemu, ale nie jest wobec niego lojalny. Widz ma janusowe oblicze - może stać się substancją społeczeństwa, kiedy reagował będzie wg racjonalnych pobudek na często nawet jego (jej) zdaniem niesprawiedliwą politykę rządzących w kraju czy w UE, ale może stać się również elementem masy, która gotowa jest zareagować natychmiast i bez zastanowienia na przejawy nawet wirtualnego zagrożenia interesu. Dla mas ważne jest więc to, że w przestrzeni medialnej zostają uchwycone ich działania. Reprezentacja takich działań pełni rolę społecznego farmakonu - w odpowiedniej ilości podana społeczeństwu i rządzącym uwrażliwia na powstały problem.

${ }^{34}$ M. Oakeshott, Masy w demokracji przedstawicielskiej, op. cit., s. 163. 
Uwrażliwienie jest w tej sytuacji zbieżne ze świadomością nieprzewidywalności następnych, podobnych do wcześniejszych reakcji, ale także ze skutkami zdarzeń, które miały miejsce lub które dopiero mogą się wydarzyć. Podana w zbyt dużej dawce prowadzi do zatrucia, otóż podmioty składające się na społeczeństwo mogą odnieść wrażenie, że tylko nagły, nieokiełznany i nieprzewidywalny w skutkach bunt może przynieść spodziewane rezultaty. Reprezentacje mogą bowiem prowadzić do tego, że bunt, jego przebieg oraz komunikacyjno-aksjologiczne implikacje, które zachodza, mogą wyznaczać normatywne zachowania wśród zbiorowości chcących kontestować rzeczywistość utrwalając schematy zachowań oraz oczekiwanych reakcji ze strony antagonizowanej „Inności”. Bunty w Europie wieków XIV-XVIII stanowiły defensywne reakcje umotywowane strachem przed zagrożeniem bądź rzeczywistym, bądź częściowo wyimaginowanym, bądź całkowicie iluzorycznym (który i tak, jak pisze Jean Delemeau, nie był odczuwany jako taki właśnie) ${ }^{35}$. Masy lubią wykorzystywać to, co jest powszechnie znane i dostępne - w perspektywie przedmiotów oraz miejsc niszczy się dobra konkretne (np. przystanki, samochody, domy, urzędy porządku publicznego, pali kukły itp.), to zniszczenie niesie ten metakomunikat, że bunt, bez względu na to, jak długo trwa, może być w swoim zasięgu wszechobecny, totalny, powszedni (jak chleb), „drobiazgowy”. Logika tego typu działań, a właściwie jej brak, został dobrze opisany przez José Ortegę Y Gasseta: „W zamieszkach wywoływanych brakiem żywności masy ludowe domagają się zazwyczaj chleba i często zdobywają go, niszcząc piekarnie. Może to posłużyć jako symbol stosunku, oczywiście przy zachowaniu należytych proporcji, współczesnych mas do cywilizacji, która je żywi [...] Masa, jaka bądź, plebejska lub «arystokratyczna», pozostawiona sama sobie, ma zawsze skłonność - z chęci do życia - do niszczenia podstaw własnej egzystencji” ${ }^{36}$.

\section{Unia Europejska - „inny innych” w polu ignorancji}

Masy lubią kryć się pod „szklanym sufitem nieufności”, co w perspektywie zjednoczonej Europy oznacza, że właśnie ze struktur unijnych oraz z ich podmiotów czynią potencjalnie ciagle aktywnego, podręcznego Innego, który może się stać bezpośrednio, pośrednio często się staje, celem antagonizmów. Bunt, w trakcie którego dochodzi do konfrontacji rządzących z niekiedy aleatorycznie uformowaną masą, jest w tym przypadku przeniesiony w szerszy kontekst, aby pokazać, że to ktoś obcy, sterując „,swoimi”, przyczynia się do jakiejś konkretnej „niesprawiedliwości”. Oczywiście, struktury UE i podmioty je tworzące nie są ontologicznie „szklanym sufitem nieufności”, ale mogą tak być postrzegane, gdyż są najbardziej poręcznym, ogólnym ,innym innych”, „uintymnionym lokalnie obcym”; czymś takim na odmiennym poziomie są lub mogą być globalizacja, amerykanizacja itp. Ta figura „innego innych” jest potrzebna w skali ogólnej do tego, aby to, co dokonuje się jednorazowo, mogło w pełni znaleźć swoje spełnienie w ofierze. Masy głoszą pochwałę ignorancji.

35 J. Delemeau, Strach w kulturze Zachodu, op. cit., s. 139.

36 J. O. Y Gasset, Bunt mas, op. cit., s. 62. 
José Ortega Y Gasset opisywał pod koniec lat trzydziestych XX wieku masy pisząc, że „dano im narzędzia pozwalające intensywnie żyć, ale nie uwarażliwiono ich na wielkie historyczne obowiązki; zaszczepiono im gwałtownie pychę i moc nowoczesnych środków działania, ale nie ducha. Dlatego też duch nie jest im do niczego potrzebny; nowe pokolenia przejmują rządy nad światem, tak jakby był on rajem, na którym nie odcisnęły się żadne ślady przeszłości i jakby nie istniały wyrastające $\mathrm{z}$ tradycji skomplikowane problemy"37. Współcześnie można przy wykorzystaniu wiedzy z zakresu nauk społecznych oraz biologicznych i antropologicznych wskazać na przyczyny takiego stanu rzeczy. Jest tak, że replikuje się nie tylko wiedza oraz przewodnie w jej rozwoju idee, rozwija się, pomnaża się także różnymi torami ignorancja, którą można definiować nie jako niepotrzebną wiedzę, ale raczej jako potrzebną niewiedzę.

W zalewie informacji, tempie ich przetwarzania, w postępującej specjalizacji wiedzy, której drugim dnem staje się wzmagająca się obojętność wobec niewiedzy (co jest w dużej mierze konsekwencją rozpadu etosu i logosu datowanego na XIX wiek), a także na skutek „przyjemnych substytutów” kompetencji (od krzyżówek począwszy na stereotypach jako źródłach wiedzy i matrycach myślenia skończywszy) człowiek wie i rozumie coraz mniej. Bez wiedzy nie ma historii, są opowieści, gry, manipulacje, uproszczenia, cywilizacyjne ,da-da”. Duch Gasseta nie przegrywa nawet z pragmatyzmem, on nawet nie staje z nim do walki; pragmatyzm oraz neopragmatyzm stają się dla człowieka masowego wyzwaniami najwyżej z obszaru ortografii, gdyż on umie niszczyć konsumując oraz konsumować niszcząc. Ignorancja jest złotym cielcem mas. Przyczyn takiego stanu rzeczy należy upatrywać w tym, czym napełnia się umysły przeciętnego widza - pozorem wiedzy, który służy za wiedzę pełną oraz wystarczającą. Media masowe doprowadziły do paradoksalnej sytuacji, w której najbardziej nawet zawiłe kwestie ekonomiczne, gospodarcze albo polityczne są podawane w takiej postaci, że oglądający je widz odnosi wrażenie, że wie, że rozumie to, co się do niego mówi, a skoro wie i rozumie, to - jeśli jego zdaniem to konieczne - musi działać.

Nowe media - poprzez takie fenomeny jak wikipedia - wzmacniają przekonanie, że to, co można powiedzieć, można powiedzieć w języku prostym i przyjemnym, a czego nie można powiedzieć, to o tym należy milczeć, dla dobra tych - $\mathrm{i}$ to jest interesujące - którzy nie umieją czegoś przedstawić w odpowiednio uproszczony sposób. Pochwała ignorancji, która jest krynicą życiodajną mas, jest bez wątpienia skutkiem upadku społecznego autorytetu etosu wiedzy, który miał swój początek w myśli pooświeceniowej, a którym zachwiała niewątpliwie niszczycielska moc mariażu racjonalności oraz technologii z okresu największych kataklizmów XX wieku. Jose Ortega Y Gasset zapowiadał tę apokaliptyczną ,symbiozę" pisząc o ludziach masowych, zbuntowanych, którzy „stawiają w stan zagrożenia samo istnienie tych właśnie zasad, którym zawdzięczają swą egzystencję. Jeśli ten typ ludzi będzie w dalszym ciągu panował w Europie - a nie ulega wątpliwości, że teraz ci właśnie ludzie o wszystkim rozstrzygają - to wystarczy trzydzieści lat, aby cały nasz kontynent cofnął się do epoki barbarzyństwa"38; wystarczyło niespełna dziesięć lat od czasu, w którym Gasset wypowiedział te słowa.

37 Ibidem, s. 53.

38 Ibidem, s. 54. 
Społeczeństwo informacyjne na poziomie treści komunikuje się poprzez to, co da się sprowadzić do informacji, na poziomie zaś życia społeczno-gospodarczego zaczyna wypluwać ten potencjał znaczeniowy oraz podmiotowy, który nie jest w stanie sprostać wymogom najnowszych technologii oraz motywowanych przez ich rozwój zawodów, a więc de facto także czerpanych z tego źródła profitów. W społeczeństwie wykorzystującym najnowsze zdobycze przekazu informacji każda pogłoska stać się może źródłem niebywałych wręcz rozruchów, zarzewiem buntu, ten pozornie niewinny „trzepot motylich skrzydeł” może wywołać burzę siejącą zniszczenie, wprowadzając zamęt i zniszczenie, chaos. Efekt asymetrii, o którym mowa, jest możliwy na skutek oddziaływania mediów masowych, w których w szybkim czasie to, co jednostkowe stać się może tym, co powszechne, światowe, globalne. Pogłoski, które nie umierają nigdy, i bunty były prawie zawsze powiązane ze sobą, „a kto mówi pogłoska, mówi strach" ${ }^{39}$.

\section{Konsumować interesy?}

W stratyfikacji interesów, którymi losowo kierują się masy, należy wskazać m.in. na przynależność zawodowa, religijną, językowa, etniczną, polityczną czy materialną, narodową, ale także każdą z nich jako tylko podobną do faktycznych. Zjednoczona Europa staje pierwszy raz w swej historii przed wyzwaniem, którym jest bunt mas mający swe możliwe przyczyny nie tylko w różnicach majątkowych, ekonomicznych, społecznych, ale także w religijnych oraz etnicznych. Pojęcie narodu w tym kontekście jest wyczerpane, dlatego masy poszukują swej relacyjnej tożsamości z tym, co lokalne, poręczne, znane oraz ewentualnie identyfikowane jako swoje. Media są przestrzenią, w której masy coraz chętniej detonują swój bunt. Masy bez mediów są ślepe. Sferą, w której UE może zneutralizować tę szaloną chęć masowej satysfakcji, są również media, bez których rządzący są niemi. Światy tworzone przez media masowe nie dadzą jednak rzeczywistej satysfakcji oraz chleba.

Kryzys ekonomiczny, który w 2009 r. w skali globalnej dotknął niemal każdą gospodarkę państwową, nie wynika jedynie z błędnych operacji finansowo-inwestycyjnych, ale także z głębokiej, nieodwracalnej deformacji źródeł dochodu społeczeństw, które żyły ze środków zarabianych wg modelu pracy, który chyli się ku upadkowi. Ideologia konsumpcji nie znajduje swej symetrii w żadnej ideologii konstrukcji. Rosną grupy społeczne, które są zajęte konsumpcją kurczy się zaś potencjał tych grup, które pracują nad ciagłością tworzenia dóbr konsumpcyjnych. Substancją mas, w innym rozumieniu „rzesz”, jest przecież między innymi bieda, która przecież nieprzerwanie istnieje na świecie, jest samą jego możliwością. „Biedota jest pod pewnym względem wieczną figurą postmodernistyczną: figurą transwersalnego, wszechobecnego, różnego, mobilnego podmiotu: dowodem nieposkromionej, aleatorycznej natury egzystencji”" ${ }^{\text {" }}$.

Współcześnie zjednoczoną Europę targały będę także bunty mas, które wyłonią się z opisanej powyżej dysproporcji. Masowość produkcji w połączeniu z jej automatyza-

39 J. Delemeau, Strach w kulturze Zachodu, op. cit., s. 140.

40 M. Hardt, A. Negri, Imperium, op. cit., s. 173. 
cją, a jednocześnie technologie wymagające coraz większych kompetencji zawodowych; ogromne dysproporcje między potencjałem demograficznym państw biedniejszych i bogatszych ${ }^{41}$; eksplozja grup ludzkich, których kwalifikacje zawodowe nie przynoszą profitów; poczucie permanentnego zagrożenia i niepokoju tworzony przez środki przekazu, który wprowadza masy odbiorców w stan odrętwienia oraz inkorporowanego poczucia bezradności, będącego reakcją na ciągle przedstawiane w mediach „nieuniknione"; negatywne traktowanie starości, która współcześnie jest nie tyle kategorią antropologiczną, co przede wszystkim ekonomiczną ${ }^{42}$; działania wojenne, które na nowo są, nawet jeśli jest to „porządnie” zakamuflowane, motywowane ekonomicznie; pękające granice penalizacji obserwowane nawet w społeczeństwach o wysokiej kontroli; kolejne nieudane projekty resocjalizacyjne oraz akulturacyjne; uprzedzenia religijne czy kulturowe - wszystkie te elementy tworzą konglomerat, w oparciu o który niezrealizowane interesy, karmione pogłoskami oraz strachem przed nieprzetrwaniem, będą źródłem buntów, powszednich tak jak niegdyś chleb w modlitwie. Zmiana modelu określającego możliwe źródła dochodu społeczeństw prowadzi bowiem do proliferacji roszczeń, która wchodzi na miejsce wytwarzanych oraz potrzebnych dóbr. Współczesny człowiek i jego wiek (ilość lat, okres, w którym podejmuje się kolejnych prac) nie stanowi sam w sobie wartości bezwzględnie dobrze zdeponowanej, co niestety widać, gdy społeczeństwa europejskie borykają się z określaniem pakietów socjalnych oraz z wyznaczaniem granic interwencjonizmu państwowego w życie jednostki. Biopolityczne ramy są w tym ujęciu potwierdzeniem ogólniejszych tendencji zmierzających ku kreacji życia społecznego jako takiego, w którym wymiary ekonomiczny ${ }^{43}$, polityczny i kulturowy przenikają się i wzbogacają coraz bardziej ${ }^{44}$. Wyżej wymienione elementy, których kolejność oraz znaczenie uwarunkowane są lokalnymi problemami i sytuacjami poszczególnych zbiorowości, szkicują jedynie horyzont możliwych

41 W badaniach przeprowadzonych przez CBOS w grudniu 1999 respondenci odnieśli się do problemu zaludnienia. Ankietowani w odpowiedzi na pytanie o największe zagrożenia wynikające z rosnącej liczby ludzi na ziem wskazali przede wszystkim na: głód (69\%), wojny (43\%), zanieczyszczenia środowiska (27\%), epidemie (23\%), wyczerpanie się zasobów naturalnych $(22 \%)$, rewolucje i niepokoje społeczne (9\%), niekontrolowane przemieszczanie się ludności (5\%). Por. www.cbos.pl (grudzień 1999).

42 W raporcie CBOS-u z 2007 roku możemy przeczytać, że: „Z obserwacji respondentów wynika, że w Polsce osoby w starszym wieku są bardzo różnie traktowane. Życzliwy stosunek do seniorów zdecydowanie dominuje - według badanych - w rodzinie (79\%), w środowisku sąsiedzkim (68\%) oraz w parafii (64\%). Osoby starsze rzadziej spotykają się z życzliwością w sklepach (46\%) i w byłym miejscu pracy $(41 \%)$. W pozostałych środowiskach przeważaja, zdaniem ankietowanych, postawy negatywne - obojętność lub niechęć; życzliwość pojawia się stosunkowo rzadko w placówkach służby zdrowia (39\%), w urzędach (32\%), na ulicy (25\%), w środkach komunikacji (20\%). Jedynie co czwarty badany (25\%) postrzega młode pokolenie jako życzliwe wobec seniorów. W latach 2000-2007 poprawiły się opinie Polaków o stosunku do osób w podeszłym wieku w rodzinie, wśród sąsiadów, w parafii, a także - w mniejszym stopniu - w byłym miejscu pracy, w placówkach handlowych oraz na ulicy”. Należy zwrócić jednak uwagę na to, co pisze autorka komunikatu, pani Bogna Wciórka, pt. Czy zmienia się stosunek Polaków do starości?: „Od środowiska i sytuacji społecznej zależy, w jakim stopniu stosunek do nich [osób starszych - przyp. autora] nacechowany jest życzliwością, w jakim zaś - obojętnością lub wręcz niechęcią". Por. B. Wciórka, Czy zmienia się stosunek Polaków do starości?, www.cbos.pl (luty 2007).

${ }^{43}$ Ch. Bretherton, J. Vogler, The European Union As a Global Actor, op. cit., s. 62-89.

44 M. Hardt, A. Negri, Imperium, op. cit., s. 9. 
buntów, które im częściej będą wybuchały, tym bardziej będą nieprzewidywalne i niszczycielskie.

Wydarzenia z 1968 roku pokazują, że mogą się na siebie nakładać dwa porządki przyczyniające się do wybuchu buntu. Pierwszy, który ma swoje bezpośrednie przyczyny oraz drugi, który nie jest już jednoznacznie, kauzalnie określony, choć okazuje się głębszy. Pierwszy odnosił się do bezpośredniej przyszłości, gdyż na skutek coraz większej liczby studentów, wzmagał się proces ich selekcji, co prowadziło m.in. do tego, że wiele osób nie mogło w najbliższej perspektywie rozwijać swoich karier, dlatego studenci domagali się m.in. zniesienia konkursów i selekcji, stałej kontroli wiedzy zamiast „loterii” egzaminu końcowego, korzystania z notatek podczas egzaminów pisemnych, możliwości pisania prac w grupach (co likwidowało tremę). Ten porządek odzwierciedlał więc krytyczną analizę systemu kształcenia, który wprowadzał nierówności w życiu społecznym; lęk ten wyrażany był przez studentów oraz ich rodziców ${ }^{45}$. Drugi porządek, głębszy, zależny jest od bardziej globalnej perspektywy. Młodzież, studenci niemal na całym świecie zaczęli bać się niebezpieczństw płynących z „nieludzkiego materializmu i rozwoju dla rozwoju"46. Technikę oraz szczęście widziano jako całkowicie rozdzielne pojęcia, a nadmiar organizacji oraz technokracja tworzą świat coraz trudniejszy do zniesienia. Jean Delemeau pisze, że w 1968 roku doszło do buntu, który łączył w sobie te dwa porządki: lęk o własną przyszłość oraz lęk o przyszłość ludzkości ${ }^{47}$. Oczywiście, do wyżej podanych przyczyn można dodać także to, że bunty z roku 1968 były reakcją pokolenia zrodzonego po II wojnie światowej na traumę wynikającą ze skali jej zniszczen ${ }^{48}$. Ta jednak interpretacja zawarta jest implicite w tym drugim porządku, gdyż pytanie o ludzkość mogło wyrastać tylko z rozczarowań względem tego, czego ta nowoczesna ludzkość już dokonała, dlatego też wielu badaczy ${ }^{49}$ mówi, że rok 1968 jest umowną datą powstania czy wyodrębnienia się postmodernizmu, gdyż wtedy właśnie „wielkie narracje” okazały się puste ${ }^{50}$. Bunt roku 1968 doprowadził niewątpliwie do wielkich przemian w całej aksjologiczno-społecznej tkance społeczeństw zachodnich, a więc jego skutki są trwałe; dlatego właśnie siłą buntu jest jego nieprzewidywalność zarówno co do przyczyn, jak i co do skutków. Bunt może wyczerpać się szybko, masy w bardzo krótkim czasie mogą być zdemobilizowane, ale to, co pozostaje - darzy pamięcią, alternatywą, prowokacją. Bunty mas w zjednoczonej Europie tworzą „,bruzdy mitu w pamięci zbiorowej” i trwały strach u rządzących.

Media masowe poprzez treści przekazów wzmacniają mityczny charakter zdarzeń, które miały miejsce, dlatego tak ważny jest język, w którym się o tym mówi oraz tak konieczna w tej perspektywie jest niemal za każdym razem figura kozła ofiarnego. Jeśli w trakcie jakichś rozruchów zginie ktoś, kto reprezentował masy, to stanie się on symbolem walki, źródłem mitycznych interpretacji sankcjonujących aberracje, których do-

45 J. Delemeau, Strach w kulturze Zachodu, op. cit., s. 139.

46 Ibidem.

47 Ibidem.

48 E. Gans, The Post-Millennial Age in: Chronicles of Love and Resentment, http://www.anthropoetics.ucla.edu/views/vw209.htm (12.09.2009).

49 M. Dąbrowski, Postmodernizm: myśl i tekst, Kraków 2000.

50 J.-F. Lyotard, Kondycja ponowoczesna: raport o stanie wiedzy, thum. M. Kowalska, J. Migasiński, Warszawa 1997. 
puszczać się będą masy. W tej perspektywie nagły bunt np. na przedmieściach Paryża, który przyniesie ofiary śmiertelne - zrodzi potrzebę rewanżu, ale także na bardzo uproszczonym poziomie stworzy wrażenie, że ci, co uciskali i przynosili śmierć - dalej są źródłem zniszczenia. W ten sposób masy deponują w figurze kozła ofiarnego nowe rozumienie sfery aksjologicznej oraz przeszłości.

\section{Odświeżanie mitu}

Odświeżanie mitu, w którym następuje substytucja bieżącej treści (konkretnej osoby lub np. rytuału) na miejsce jej starszych odpowiedników jest konieczna ze względu na to, że masy nie radzą sobie z linearnym porządkiem chronologicznym wymagającym ciągłości trwania $\mathrm{w}$ czasie zgodnie $\mathrm{z}$ jego kierunkiem od przeszłości ku przyszłości. Figura kozła ofiarnego pełni funkcje temporalne - jest „,bieżącym (teraźniejszym) zawsze", masy żyją teraźniejszością, a buntują się kierując się podobieństwami, nawet $\mathrm{w}$ ich uproszczonej postaci, czyli analogiami. Jeśli rządzący odpowiedzą na przemoc przemoca, to w ten sposób prowadzą do stygmatyzacji zdarzeń, osób, rzeczy - i powołują w ten sposób mit, i powołują tą drogą nowych świętych, i nadają w ten sposób sens chaotycznie oraz nerwowo reagującej masie.

Często brak reakcji rządzących jest wyrazem ich słabości, którą najlepiej wyczuwa nie widz przed ekranem telewizora, nie masa, ale społeczeństwo, które zwyczajnie odczuwa trwogę z powodu bliskiego niebezpieczeństwa zdarzeń. Bierność rządzących jest więc rzadkością, gdyż bunt mas ma często zbyt destruktywny wymiar, który atakuje bastiony społecznego konformizmu. Bez ofiary i poświęcenia, bez stygmatyzacji zdarzeń nie ma święta, nie ma „usprawiedliwianej” przemocy, nie ma sensu. Bunty często powstają po to, by wykuć w kruszcu obojętności oraz ignorancji świętych dnia teraźniejszego trwającego na „medialne” zawsze (czyli do następnej ofiary, choć zdarza się, że kultura popularna zawłaszcza o kimś pamięć i w zbiorowej świadomości oraz wiedzy tworzy oraz powiela mit o niej).

Bunt - czy myśli się o tym, co miało miejsce w epokach przednowoczesnych, czy też współcześnie - karmi się przemocą i świętem. Z dialektyki tych dwóch porządków wyłania się możliwość powtarzalności zdarzeń oraz proteza sensu, która jest niezwykle ważna dla mas, jeśli te chcą satysfakcji. Masy są genitalne, popędliwe, dlatego powtarzalność jest substytutem porządku, który, jak odnoszą one wrażenie, wprowadzają lub rekonstruują (stąd tak ważna mimetyczna relacja wynikająca z naśladowania rządzących). Potrzebują one zaś sensu dla swych działań, gdyż sens jak najbardziej nawet ulotny i umowny, za każdym razem artykułowany w inny sposób, różnie też pojmowany, jest tym, co je wiąże od środka. Masy mogą wreszcie zagłosować w wyborach i tu nieprzewidywalna reakcja, upiornie kontrolowana przez opinię publiczną, współczesną wyrocznię, jest tym, co budzi czujność wśród rządzących oraz niepokój w społeczeństwie.

W perspektywie aktywności mas formuły neoliberalne są współczesnymi postaciami utopii. Nie proponują one niczego rzeczywistego, wskazując na konieczność indywidualnej pracy podmiotu. Ujęcia neoliberalne są w tym kontekście adresowane do tych, których aktywność lub chęć działania ogranicza się do roszczeń, do pasywności (w takim stanie masy mogą z korzyścią dla siebie trwać długo). Postulaty modeli neoli- 
beralnych są zrozumiałe dla tych, którzy je tworza, ich wzory myślenia są niedostępne dla mas, dlatego pogłębiają one różnice między masami a społeczeństwem, między masami a rządzącymi.

Słabością zjednoczonej, a właściwie jednoczącej się Europy jest jednak to, że jej polityka (lub polityka jej członków i współtworzących ją struktur) wzmacnia potęgę mas pozbawioną skonkretyzowanych zamierzeń, oczekiwań czy ideałów. Polityka współczesna jest raczej awangardowa, w takim znaczeniu, że to rządzący próbują rozpoznać przestrzeń możliwych wyładowań zbuntowanych mas i umizgując się przed nimi - starają się ,nastrajać” rzeczywistość społeczną, aby na przykład poprzez takie zabiegi przetapiać masy na - w miarę kontrolowanych, skutecznych - wyborców. Podmiotem stają się niszczący przestrzeń publiczną oraz promujący przemoc kibice na równi ze związkami zawodowymi, w perspektywie ewentualnych wyborów tak różne grupy potencjalnie brzemienne masami są istotne, gdyż odpowiednia ich stymulacja może się opłacać rządzącym. Człowiek masowy śpi czujnie pod skórą każdego obywatela. 